\title{
POLYMERASE CHAIN REACTION FOR DIFFERENTIATION BETWEEN SOME CAPRIPOX VIRUS ISOLATES
}

Omyma, A.Shemies"; Hanan, A.Fahmy"; Jehan,A. Gafer" and Nahed A. Mahmoud"

Virology Res.Dept," Biotechnology Res.Dept.,Animal Health Research Institute, Dokki.

\section{ABSTRACT}

A total number of 38 clinical specimens of skin lesions from diseased animals (17 cattle and 21 sheep) of both sex and of different ages were investigated for lumpy skin disease virus (LSDV) and sheep pox virus (ShPV). Bovine samples obtained from (Shubra Shehab station, Qalubia Governorate) with $60 \%$ morbidity and $8 \%$ mortality especially in young animals. The clinical examination revealed the presence of nodules found most numerous on head and neck of the animal and may cover whole body with some eruption of skin nodules. Ovine samples obtained from sheep housed in (Sakha station, Kafr El-sheikh Governorate) with $70 \%$ morbidity and $20 \%$ mortality especially in kids 3-4 month old. The affected sheep was suffering from papules with hard swelling may covered by fluid filled vesicles in axilla and perineum region with enlargement of superficial lymph nodes. The two viruses were successfully isolated on ECE and tissue culture and identified using agar gel precipitation test (AGPT), fluorescent antibody technique and virus neutralization test (VNT) with sensitivity of $42.2 \%$, $71.1 \%$ and $65.8 \%$ respectively. The two viruses were differentiated using multiplex polymerase chain reaction (MPCR) with speciesspecific primers for LSDV and ShPV of different amplicon sizes about $192 \mathrm{bp}$ and $289 \mathrm{bp}$ respectively with high specificity and sensitivity with speed and do not require nucleotide sequencing or restriction analysis of PCR products. Therefore MPCR shown to be the method of choice for differentiation between some Capripox virus isolates and diagnosis directly from clinical specimens. 


\section{INTRODUCTION}

Capripoxviruses (CaPVs) represent one of eight genera within the Chrodopox virinae (ChPV) subfamily of the Poxviridae family. The capripoxvirus genus is currently composed of three closely related viruses: Lumpy skin disease virus (LSDV), sheep poxvirus (ShPV), and goat poxvirus (GPV) (Tulman et al., 2001, Adama and Gerrit 2007 and Balinsky et al., 2007). OIE includes these diseases in list A of the most dangerous animal diseases, which can cause epizootics entailing great economic loss. (Orlova et al., 2006).

The virion is brick shaped particle 170 to 260 by 300 to $450-\mathrm{nm}$ diameter capsid contain a linear, non segmented, double-stranded DNA genome of approximately 150 kilo bases that is surrounded by lipid that is not true envelope (Moss, 2001). CaPVs tend to be host specific, however incidences where ShPV and GPV have crossed species into goats and sheep respectively have documented (Munz and Dumbell, 1994).

ShPV and GPV often transmitted by respiratory route during close contact, abraded skin, or transmitted mechanically by insect, but LSDV transmitted primary by biting insects (OIE, 2008).

LSD is mainly confined to Sub-Saharan Africa suggesting that they are caused by distinct viruses (Mondal et al., 2004). ShPV and GPV are endemic to Asia, and Africa south of the equator, particulary to the north and west of the Sahara (Orlova et al., 2006). Lastly, theses viruses could be isolated from recent outbreaks in Yemen and Vietnam (Babiuk et al., 2009). The only confirmed LSD case in cattle occurred in Israel in years 1989, 2006 and 2007 (Starm et al., 2008). 
ShPV and GPV genomes are very similar to that of LSDV, sharing 97\% nucleotide identity. However LSDV contain its unique genes not found in the ShPV and GPV. The absence of these genes in ShPV and GPV suggests a significant role for them in bovine host range (Tulman et al., 2002).

LSD (psudourticaria, Neethling virus disease) is a pox viral disease of cattle with significant morbidity. Losses occur from decreased milk production, abortion, infertility, loss of condition and damaged hides. The development of nodules may penetrate the full thickness of skin and sometimes the underlying muscle. The necrotic material separated from adjacent skin (sit fast). Deep holes or scars are often left in skin (OIE, 2008).

LSD disease was recognized in Egypt in Suez Governorate in May 1988 and Ismailia by Ali et al., (1990), House et al., (1990) and (Saber, 1992). Another outbreak was reported among cattle in El- Menia Governorates, Upper Egypt in July 1998 (Abd El-Rahim et al., 2002). A new rash of LSD cases appeared in July 2006 and has proven more difficult to control Daily Star Egypt Staff (2006). About 15 outbreaks in 5 Governments Ismailia, BeniSweif, Al Beheira, New Valley and Monoufiya.

Sheep pox is contagious viral disease of sheep. This disease may be mild in endemic areas, but are often fatal in newly introduced animals. Economic losses result from decreased milk production, damage to the quality of hides and wool. The disease can limit trade and prevent the development of intensive livestock production $\boldsymbol{O I E}$ (2008). The disease was reported in Egypt by many authors Sabban (1957), Soad et al., (1996),Agag et al.,(1997), Tawfik et al.,(2001) and Nawal et al., (2006). 
In Egypt, although the vaccination programs of both viruses were applied annually, epidemics occurred in Egypt from time to time (Agag et al., 1997 and Mohammed, 2000).

Unfortunately serological distinction between CaPVs is not possible, previous classification was based only on animal host origin but today differentiation is possible using genomic DNA. Therefore our article was planed to isolate these viruses and the application of modern, recent and accurate technique as multiplex PCR as a sensitive reliable test for detection and differentiation of CaPVs.

\section{MATERIAL \& METHODS}

Animals: A total number of 38 diseased animals (17 cattle and 21 sheep) of both sex and of different ages were subjected for this work. Bovine samples obtained from Shubra Shihab station, El Kanater El Khairea, El Qalubia Governorate with 60\% morbidity and 8\% mortality especially in young animals. All the animals were vaccinated by sheep pox vaccine. Ovine samples obtained from Sakha station and Kafr EL Sheikh Governorate with $70 \%$ morbidity and $20 \%$ mortality especially in kids 3-4 month old.

Sample collection and preparation: The samples were sent to the laboratory as soon as possible and treated according to $\boldsymbol{O I E}$ (2008). Skin biopsies comprising epidermis, dermis and subcutis of the nodules were minced and ground in a sterile pestle and mortar with sterile sand then $10 \%$ suspension was prepared in sterile PBS containing sodium penicillin (1000 IU/ml), streptomycin sulphate $(1 \mathrm{mg} / \mathrm{ml})$ and mycostatin $(100 \mathrm{IU} / \mathrm{ml})$. The suspension is freeze-thawed three cycles and then partially clarified by centrifugation at $3000 \mathrm{rpm} / 10$ minutes, the supernatant fluid was stored at $-20^{\circ} \mathrm{c}$ until used for virus isolation on ECE and Tissue culture. 
Virus isolation:

1) On embryonated chicken egg (ECE): The isolation was applied according to House et al., 1990. Specific pathogen free (SPF)-ECE were obtained from National Laboratory for Quality Control on poultry production (NLQP), Dokki, used for virus isolation by inoculation via CAM rout (11-13days old embryos) and incubated at $35^{\circ} \mathrm{c}$ and $70 \%$ humidity for 5 days post inoculation.

2) On tissue culture: Vero cell culture as well as Maddien Derby bovine kidney(MDBK) were used for virus isolation. The cultures were obtained from Virology Dept, Animal Health Res. Institute, Cairo. Samples were inoculated for three passages on tissue culture (Vero cell for ovine sample and MDBK cell for the bovine sample) according to Carn and Kitching (1995). The infectivity titer was $10^{3.2} \mathrm{TCID}_{50} / \mathrm{ml}$ for LSDV, while it was $10^{3.4}$ for ShPV.

\section{Virus identification:}

1) Agar Gel precipitation test (AGPT): The technique was applied according to $\boldsymbol{O I E}$ (1989) for identification of the isolated viruses in concentrated infected tissue cultures and in $10 \%$ suspensions of inoculated CAM by using hyperimmune serum kindly obtained from pox Dept, Serum and Vaccine Research Institute, Abbasia,

2) Direct fluorescent antibody technique (FAT): It was carried out according to Kitching and Hammond (1992). Briefly, the infected cultures fixed in acetone at $-20^{\circ} \mathrm{C}$ for 10 minutes and stored at $4{ }^{\circ} \mathrm{C}$ till staining with antibovine fluorescein isothiocyanate conjugates was supplied by Virology Dept Animal Health Res. Institute, Dokki, 
3) Virus neutralization test: The test performed according to Pandy and Singh (1970). Neutralization procedure using hyperimmune serum supplied from pox department, serum and vaccine research Institute, Abbasia, Cairo.

4) Multiplex polymerase chain reaction (MPCR): The technique was applied according to Orlova et al., (2006), using species-specific different primers with different amplicons in a singl tube.

DNA Extraction: The DNAs extracted from samples as well as from isolated viruses as described by Sambrook et al., (1989) phenol chloroform method. The infected cell lysate $10 \%$ scab suspension were clarified by centrifugation at $1500 \mathrm{~g}$ for $10 \mathrm{~min}$ followed by extraction with phenol: chloroform: isoamyl alcohol (25:24:1). The DNA was precipitated with absolute ethanol and finally dissolved in 30ul of nuclease free water after air drying the pellet.

DNA amplification: The extracted DNAs was amplified using oligonucleotid primers for LSDV designed according to the sequence of viral attachment protein encoding gene published by Ireland and Binepal (1998). The size of the amplicon is $192 \mathrm{bp}$ the primers have the following gene sequences:

- Forward pimer 5'- TTT-CCT-GAT-TTT-TCT-TAC-TAT-3

- Reverse primer 5'-AAA-TTA-TAT-ACG-TAA-ATA-AC-3'

The oligonucleotide primers for sheep pox were prepared according to the published data of the inverted terminal repeats (ITRs) gene by Black et al.,(1986) and Gershon and Black (1989). The size of amplicon is $289 \mathrm{bp}$ the primer have the following gene sequence:

- Forward primer 5'-AGA-AAC-GAG-GTC-TCG-AAG-CA-3'

- Reverse primer 5'- GGA-GGT-TGC-TGG-AAA-TGT-GT-3' 
The primers were synthesized by MWG-Biotech(Eberberg, Germany). The amplification was carried out according to OIE (2008). A final volume of 50ul containing: $5 \mathrm{ul}$ of $10 \mathrm{X}$ PCR buffer, $1.5 \mathrm{ul}$ of $\mathrm{MgCL}_{2}(50 \mathrm{mM}), 1 \mathrm{ul}$ of dNTP $(10 \mathrm{mM}), 1 \mathrm{ul}$ of each primer, $1 \mathrm{ul}$ of DNA template, $0.5 \mathrm{ul}$ of Taq DNA polymerase then added nuclease-free water to the final volume. The sample were incubated in the Thermal cycler (MJ incorporation, USA) programmed to perform initial denaturation step 2 minutes at $95^{\circ} \mathrm{C}$ followed by 35 cycles consisting of ( 45 second at $95^{\circ} \mathrm{c}$ for denaturation, 50 second at $50^{\circ} \mathrm{c}$ for primer annealing, 1 minute at $72^{\circ} \mathrm{c}$ for extension) then 2 minutes at $72^{\circ} \mathrm{c}$ for final extension. Lastly the products holded in the thermal cycler at $4^{\circ} \mathrm{c}$ until analysis.

Analysis of PCR products using agar gel electrophoresis: The analysis was carried out according to Sambrook et al., (1989). Briefly 10ul of each PCR product was loaded on $1.5 \%$ agarose gel, containing $1 \mathrm{ul} / \mathrm{ml}$ ethidium bromide in Tris-acetate buffer and visualized under ultra violet transilluminator. Positive control viruses (supplied from pox Dept. Serum and Vaccine Res. Institute, Abbasia, Cairo) as well as negative control and 100 bp DNA-Marker Ladder were also included in the test.

\section{RESULTS}

In this study, the clinical observation of affected animals revealed presence of fever as first clinical signs, skin lesions, in addition to swelling of lymph nodes, congestion of oral, nasal and ocular mucous membranes. The lesions range from few skin nodules in mild cases to large number of nodules covering the whole body in severely affected cases. By inoculation on CAM of SPF-ECE characteristic inflammatory edematous spots (pock lesions) were seen five days post inoculation (after $1^{\text {st }}$ passage and become clear after $3^{\text {rd }}$ passage) while embryonic death does not occur (photo 1). 
The inoculations on tissue cultures have successfully produced characteristic CPE consisting of retraction of cell membrane from surrounding cells and eventually rounding of cells 8 days post inoculation. Three passages were done for viruses isolation. The isolated viruses were identified using AGPT, the results are presented in table (1). A clear precipitation lines were appeared (as a positive results) against reference LSDV and ShPV antisera. Regard with fluorescent antibody technique positive samples showed small fluorescent granules in the cytoplasm (photo 2), while the stained non infected control cells showed no fluorescence. Results of the test are recorded in table (2). The isolated viruses were identified also using virus neutralization test the results are documented in table (3). The viral attachment protein primers as well as the inverted terminal repeats gene primers used in PCR amplification produced the expected amplicon sizes of 192 bp and 289 bp for LSDV and ShPV respectively, while no PCR product was observed from negative control (photo 3).

Table (1): Identification of the isolated virus by Agar gel precipitation test (AGPT) using reference anti LSDV and ShPV antisera.

\begin{tabular}{|c|c|c|c|c|c|}
\hline \multirow{2}{*}{ Animal } & \multirow{2}{*}{ No. of sample } & \multicolumn{2}{|c|}{ Results } & \multirow{2}{*}{ Suspected virus } & \multirow{2}{*}{$\%$} \\
\hline & & $+\mathrm{Ve}$ & $-V e$ & & \\
\hline Cattle & 17 & 7 & 10 & LSDV & 41.2 \\
\hline Sheep & 21 & 9 & 12 & ShPV & 42.9 \\
\hline Total No. & 38 & 16 & 22 & & 42.1 \\
\hline
\end{tabular}

LSDV: Lumpy skin disease virus.

ShPV: Sheep pox virus.

Kafrelsheikh Vet. Med. J. Vol. 7 No. 1 (2009) 
Polymerase Chain Reaction For Differentiation Between ...

Table (2): Identification of the isolated viruses by fluorescent antibody technique.

\begin{tabular}{|c|c|c|c|c|c|}
\hline \multirow{2}{*}{ Animal } & \multirow{2}{*}{ No. of sample } & \multicolumn{2}{|c|}{ Results } & \multirow{2}{*}{ Suspected virus } & \multirow{2}{*}{$\%$} \\
\hline & & $+\mathrm{Ve}$ & $-\mathrm{Ve}$ & & \\
\hline Cattle & 17 & 12 & 5 & LSDV & 70.6 \\
\hline Sheep & 21 & 15 & 6 & ShPV & 71.4 \\
\hline Total No. & 38 & 27 & 11 & & 71.1 \\
\hline
\end{tabular}

Table (3): Identification of the isolated viruses using virus neutralization test (VNT) with antiserum (1:20).

\begin{tabular}{|c|c|c|c|c|c|c|c|c|c|c|}
\hline \multirow{2}{*}{ Animal } & \multirow{2}{*}{$\begin{array}{l}\text { No. of } \\
\text { sample }\end{array}$} & \multicolumn{2}{|c|}{ Results } & \multicolumn{5}{|c|}{ Titer No. of isolates } & \multirow{2}{*}{$\begin{array}{c}\text { Suspected } \\
\text { virus }\end{array}$} & \multirow{2}{*}{$\%$} \\
\hline & & $+\mathrm{Ve}$ & $-\mathrm{Ve}$ & $1 / 8$ & 1/16 & $1 / 32$ & $1 / 64$ & $1 / 128$ & & \\
\hline Cattle & 17 & 11 & 6 & - & 1 & 3 & 5 & 2 & LSDV & 64.7 \\
\hline Sheep & 21 & 14 & 7 & 2 & 4 & 1 & 4 & 3 & ShPV & 66.7 \\
\hline Total No. & 38 & 25 & 13 & & & & & & & 65.8 \\
\hline
\end{tabular}

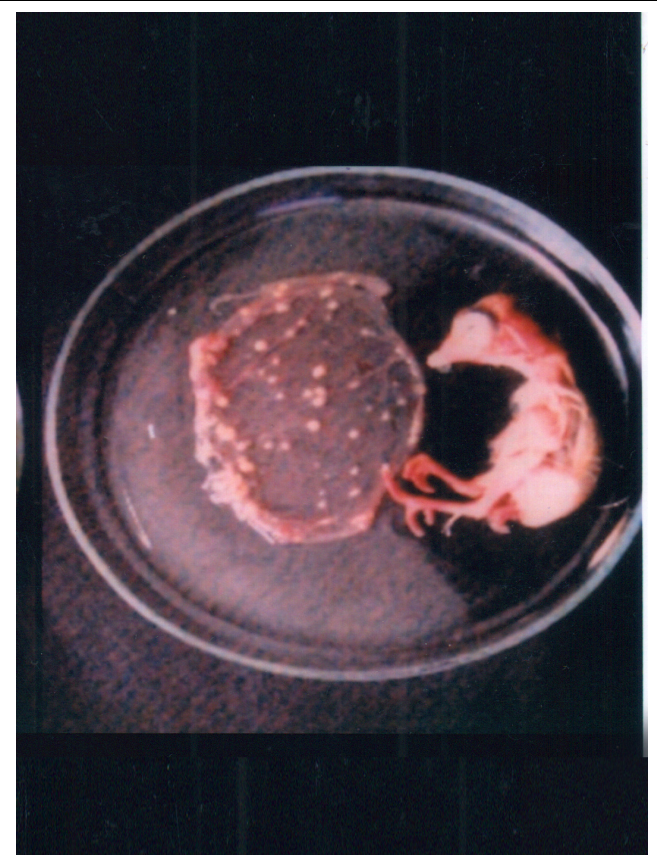

Photo (1): Characteristic inflammatory odematous spots (pock lesions) on specific pathogen free (SPF) - embryonated chicken egg (ECE). 


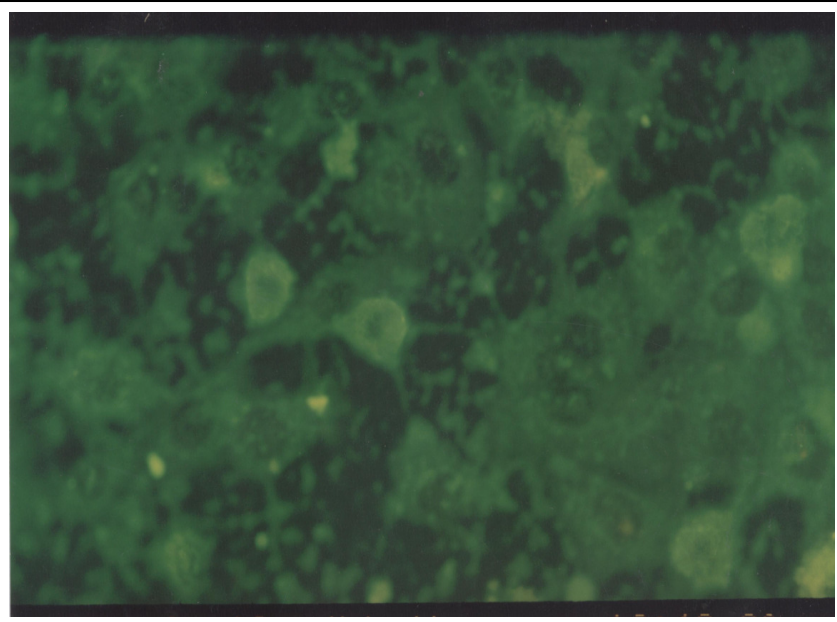

Photo (2): Fluorescent antibody technique in the cytoplasm of infected MDBK cells.

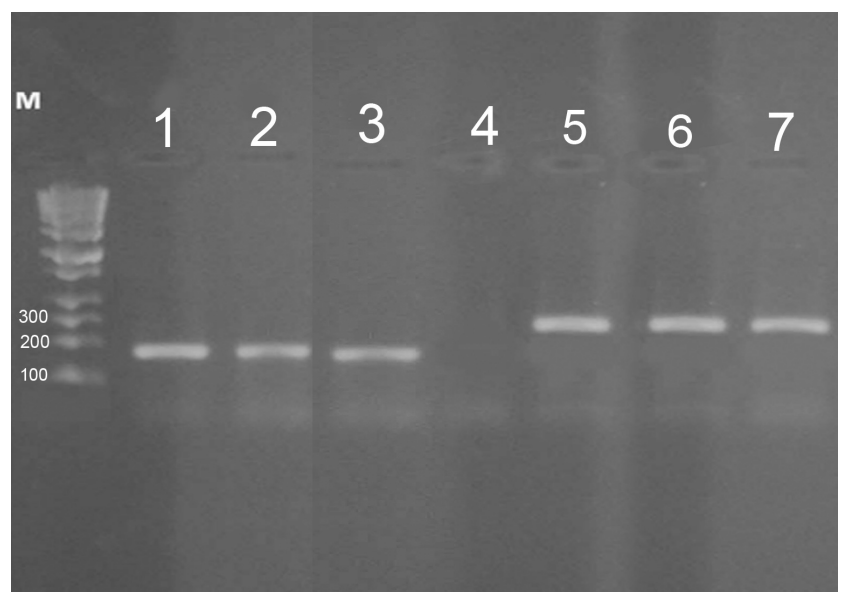

Photo (3): PCR amplification of isolated LSDV and ShPV. PCR products were electrophoresed on $1.5 \%$ agarose gel, with ethidium bromide and visualized under an ultraviolet transilluminator. M: Molecular weight marker, 100 bp DNA Marker Ladder. Lan (1): PCR amplification product of LSDV from tissue culture. Lan (2): LSDV from skin biopsy. Lan (3): Positive control for LSDV. Lan (4): Negative control. Lan (5): ShPV from tissue culture. Lan (6): ShPV from skin biopsy. Lan (7): Positive control for ShPV. 


\section{DISCUSSION}

Capripoxvirus infections including ShPV, GPV and LSDV, which are listed by the OIE, are malignant, severe and highly contagious diseases in sheep, goats and cattle respectively (Yazici et al., 2008). Sheep pox occupies an important place in the livestocks industries and contributes significantly to the world economy as the disease threatens animal population, inflicts substantial losses, reduces productivity and lower quality of wool (Kitching and Carn, 1996). In addition, sheep pox virus are extremely host specific Rao and Bandyo-padhyay (2000).

Comparative genomic data by Tulman et al., (2002) indicate the close genetic relationship among Capripoxviruses, and they suggest that ShPV and GPV are distinct and likely derived from an LSDV - like ancestor. Laboratory diagnosis is based on clinical signs and serological tests such as virus neutralization, immunofluorescence, agar gel immunodiffusion techniques, ELISA, virus isolation or electron microscopy (Oguzoglu et al., 2006). These technique are time-consuming, difficult to apply routinely with difficulty in term of cross-reaction with the ORF virus (ManaganaVougioka et al., 2000).

Although recent molecular studies suggest that capripox virus genus including sheep pox, goat pox and LSDV are very similar in term of antigenic characteristics; these viruses are phylogenetically distinct and can be differentiated by accurate molecular techniques (Bhanuprakash et al., 2006).

Capripoxvirus P32 antigen is a structural protein present in all strains of CaPV. Western blot analysis for LSDV, P32 reacts with hyper immune serum after analyzed by sodium dodecyl sulfate (SDS - PAGE) 
in plyacrylamide gel electrophoresis (Hanan and Aggour, 2002). Restriction endonuclease analysis can be used to distinguish LSDV from ShPV after digestion of their DNA with Hind III and electrophoresis of the DNA fragment in agarose gel (Hanan, 2003).

In this study, the clinical observation of the animals revealed difference in severity of the disease reflecting individual variation between animals and the susceptibility of small animals the same observation was previously reported by House, (1992) Barnard et al., (1994) and Joshi et al.,(1999).

The skin biopsies used in this work for the detection of the viruses as biopsy material is easy to obtain (Ireland and Binepal, 1998). Regard with AGPT table (1), FAT table (2), photo (2) and VNT table (3) used in this work for the identification of the viruses both tests gave sensitivity of $42.2 \% 71.1 \%$ and $65.8 \%$ respectively these results agree with previous study of (Mangana-Vougiouka et al., 2000).

Virus neutralization test is the most specific serological tests, but because the immunity to LSDV and sheep pox virus infection is predominantly cell mediated so the test is not sufficiently sensitive to identify animals that have had contact with LSDV or sheep pox virus and developed only low level of neutralizing antibody. AGPT table (1) and FAT table (2) are less specific due to cross reaction with antibody to other poxvirus OIE (2008).

As animals are most contagious before neutralizing antibodies develop, that occurs approximately a week after the onset of the clinical signs. These neutralizing antibodies can interfere with virus isolation and some antigen-detection tests. As we know that, all viruses of capripox virus 
genus share a common major antigen for neutralizing antibodies and it is not possible to distinguish strains of Capripox virus from cattle, sheep and goats using serological techniques (OIE, 2008). Therefore our article planed to fulfill towards the application of PCR technique in detection and differentiation of some Capripox virus.

The PCR technique could be done on the biopsy materials and does not require low temperature storage, results can be obtained in a few hours, and can be used later in the course of the disease when virus-specific antibodies are present (Iman et al., 2007). The test is also suitable for use in those countries in which the disease is not endemic and live virus is not available (Heine et al., 1999).

In this work, a fast and simple method for capripox virus species identification has been applied. The method is based on multiplex polymerase chain reaction (MPCR) with species-specific primers photo (3) and does not requires nucleotide sequencing or restriction analysis of PCR products as mentioned by Orlova et al., (2006). Previous studies reported that multiplex PCR technique is an essential cost-saving technique for large-scale genotyping with significant scientific, clinical and commercial applications Shi, (2001). A duplex PCR was developed and optimized for simultaneous detection and differentiation of capripox virus and orf virus (Zheng et al., 2007).

Regard with the results of multiplex PCR technique photo (3), the viral attachment protein gene primers as well as the inverted terminal repeats gene primers used in PCR amplification produced the expected amplicon sizes of 192bp and 289bp for LSDV and ShPV respectively. Even samples that were negative were proved positive with PCR technique 
using these specific primers. This observation indicates that PCR technique is more sensitive than other diagnostic tests. This result agreed with those obtained by (Managana-Vougiouka et al., 2000 and Tuppurainen et al., 2005). Polymerase chain reaction (PCR) assays targeting viral attachment gene sequences of capripox viruses have also been reported for detection of capripox viruses in skin biopsies and infected culture fluid (Ireland and Binepal, 1998, Heine et al., 1999, Managana-Vougiouka et al., 1999, Parthiban et al., 2005 and Ahmed and Kawther 2008). The same primers of inverted terminal repeats gene sequence were successfully used by (Black et al., 1986 and Gershon and Black 1989).

\section{CONCLUSION}

Outbreaks can be controlled by quarantines, movement controls, followed by stringent cleaning and disinfection of farms and equipment. Proper disposal of infected carcasses. Vaccination may also be considered. Insecticides and repellent may also be helpful to control spread of LSDV. Antibiotics are used to control secondary infection. We can conclude that PCR technique described combines high specificity and sensitivity with speed. Also MPCR assay can be successfully used for simultaneous detection and differentiation of capripox virus.

\section{REFERENCE}

- Abd El- Rahim, S. El- Ballal and Hussein, M (2002): Lumpy skin disease. !'st Sci. Cong. Monofia University, Sadat City. Cairo Egypt 23-24 April 2002.

- Adama, D. and Gerrit, J.V. (2007): Genus Capripoxvirus. In Pox viruses pp: 167-181. 
- Agag, B.I; Dawlat, M. Amin; Hossam, M; Mousa, SH.M. and Nariman, M.R. (1997): Sheep pox infection among finishing landarc lambs" $4^{\text {th }}$ SCi. Cong. Egypt Soc. For cattle disease 79 Dec) 19 Assuit Egypt. Proceeding.

- Ahmed, W.M. and Kawther, S. Zaher (2008): Observation on lumpy skin disease in local Egyptian cows with emphasis on its impact on ovarian function. African. J of Microbiology Research Vol. 2 pp. 252257.

- Ali, A.A.; Esmat, M.; Attia, H. and Selim, A. (1990): Clinical and pathological studies on lumpy skin disease in lower Egypt $4^{\text {th }}$ Sci. Cong. Fac. Vet. Med. Assuit Univ.pp. 892-899.

- Babiuk, S.; Timothy, R.B. and Geoff, P.(2009): Yemen and Vietnam capripox viruses demonstrate distinct host preference for goats compared with sheep. J Gen. Virol. 90, 105-14.

- Balinsky, C. A.; Delhon, G.; Afonso, C. L.; Risatti, G. R.; Borea, M. V.; French, R. A.; Tulman, E. R.; Geary, S. J. and Rock, D. L. (2007): Sheeppox virus kelch-like gene SPPV-019 affects virus virulence. J Virol. 81 (20), 11392-11401.

- Barnard, B.J.H.; Munz, E.; Dumbell, K. and Prozesky, L. (1994): " Lumpy skin disease. In : Infectious disease livestock. Ed.; Oxford University Press, Captown, PP. 604-612.

- Bhanuprakash, V.; Indrani, B.K.; Hosamani, M. and Singh, R.K. (2006): The current status of sheep pox disease. Comp. Immun., Microb. and Infectious Dis. 29, 27-60. 
- Black, D.N.; Hammond, J.M. and Kitching, R.P. (1986): "Genomic relationship between capripox viruses" Virus Res., 5: 277-292.

- Carn, V.M. and Kitching, R.P. (1995): The clinical response of cattle experimentally infected with lumpy skin disease (Neethling) virus "Arch. Virol., 140: 503-513.

- Daily star Egypt staff (2006): Lumpy skin disease" threatens food security, Say Agricultural Experts. July 12 (2006).

- Gershon, P. D. and Black, D.N. (1989): A capripoxvirus pseudogene whose only intact homologs are in other pox virus genomes "Virology" 172: 350-354.

- Hanan, A. Fahmy (2003): Studies on genomic characterization of lumpy skin disease virus and sheep pox virus J. Egypt. Vet. Med. Assoc.63 (4) 201-207. 26th Arab Vet. M. Congress October 4 - 7.

- Hanan, A. Fahmy and Aggour M (2002): Electrophoretic characterization and immunological studies on lumpy skin disease virus. J. Egypt. Vet. Med. Assoc. 62 (6B) 147-154.

- Heine, H.G.; Stevens, M.P.; Foord, A.J. and Boyle, D.B. (1999): A Capri pox detection PCR and antibody ELISA based on the major antigen $\mathrm{P}_{32}$, homologue of vaccinia $\mathrm{H} 3 \mathrm{~L}$ gene. Journal of immunological methods. 227, 187-196.

- House,J.A.(1992): Sheep and goat pox. Veterinary Diagnostic Virology, 217-219. 
- House, A.J.; Wilson, T.M.; El-Nakashly, S.; Karim, I.A.; Ismail, I.; El-Danaf,; Mousa, A.N. and Ayoub, N.N. (1990): The isolation of lumpy skin disease virus and bovine herps virus from cattle in Egypt. J. Vet. Diagn. Inest., 2:111-115.

- Iman,M. Bastawecy; Aly, W.F.; Nelly, O. Aly and Saad, A.A. (2007): Accurate and rapid techniques for laboratory diagnosis of lumpy skin diease. J. Egypt. Vet. Med. Assoc. 67, (1): 133-147.

- Ireland,D.C.and Binepal,Y.S.(1998):Improved detection of capripox virus in biopsy samples by PCR. J. Virol. Methods, 74, pp1-7.

- Joshi, R.K.; Ali, S.L.; Sanjay, S. and Rao, V. N. (1999): Clinicoepidemiological studies on a natural outbreak of goat pox in Madhya Pradesh. Indian Vet. J. 76 (4): 279-281.

- Kitching, R.P. and Hammond, J. M. (1992): Poxvirus, infection and immunity. In: Encyclopaedia of immunology. $3^{\text {rd }}$ edition, Vol. 3, pp. 1261-1264.

- Kitching, R.P. and Carn, V.M. (1996): Sheep pox and goat pox. In: OIE Manual of standards for diagnostic tests and vaccine, $3^{\text {rd }}$ OIE, Paris, France, pp. 11-127.

- Managana-Vougiouka,O.; Markoulatos, P.; Koptopoulos, G.; Nomikou, K.; Bakandritsos, N. and Papadopoulos, O. (1999): Sheep pox virus identification by PCR in cell culture. J. Virol. Meth., 77: 75-79.

- Managana-Vougiouka,O.; Markoulatos, P.; Koptopoulos, G.; Nomikou, K.; Bakandritsos, N. and Papadopoulos, O. (2000): Sheep pox virus identification from clinical specimens by PCR, cell culture, immunofluorescence and agar gel immuno precipitation assay. Molecular and cellular probes $14,305-310$. 
- Mohammed, A.E. (2000): Effect of different inactivation on sheep pox virus" M.V.Sc Thesis Faculty of Veterinary Medicine, Microbiology department, Zagazig University.

- Mondal,B.;Hosamani,M.;Dutta,T.K.; Senthilkumar, V. S.; Rathore, R. and Singh, R. K. (2004): An outbreak of sheep pox on a sheep breeding farm in Jammu India. Rev. Sci. Tech. Off. Int. Epiz. 23 (3): 943-949.

- Moss, B. (2001): Poxviridae: the viruses and their replication. Pp 2849-2884. In D.M. Knipe and P.M. Howley (Ed. Virology).

- Munz,E. and Dumbell, K. (1994): Sheep pox and goat pox. Infectious diseases livestock, Vol. (1): pp 613-615.

- Nawal, M. A. Youssef; Omayma, A. Shemies; Nahed, A. Mahmoud and Mervat, M. Mahmoud (2006): Isolation, Identificatio and Electrophoritic analysis of some pox viruses in Egypt. Alex. J. Vet. Science. 24 (1): 25-37.

- Oguzoglu, T.C.; Alkan, F.; Ozkul, A.; Atalay-Vural , S.; Gungor, A.B. and Burgu, I. (2006): A sheep pox virus outbreak in central turkey in 2003: Isolation and Identification of capripox virus. Vet. Res. Communications 30, 965-971.

- OIE (1989): Manual of Recommended Diagnostic Techniques and Requirements for Biological products for list $\mathrm{A}$ and $\mathrm{B}$ diseases. International committee of the OIE. Vol. 1 pp. 1/8-8/8.

- OIE Terrestrial Manual (2008): Lumpy skin disease chapter 2. 4. 14. pp. 768-778. 
- Orlova, E.; Shcherbakov,; Diev, V. and Zakharov, V. (2006): Differentiation of capripox virus species and strains by polymerase chain reaction. Applied Molecular biology. 40. (1): 139-145.

- Pandy, R. and Singh, I.P. (1970): Cytopathogencity and neutralization of sheep pox virus in primary cell culture of ovine and caprine origin. Ind. Pathol. Bact., 13: 6-11.

- Parthiban, M.; Govindarajan, R.; Manoharan, S.; Purushothaman, V.; Daniel Joychandran, N. and Koteeswaran, A. (2005): Comparative sequence analysis of diagnostic PCR amplicons from Indian sheep pox virus. Veteinarski Archiv 75 (3): 203-9.

- Rao,T.V.S.and Bandyo-pahyay,S.K.(2000): A comprehensive review of goat pox and sheep pox and their diagnosis. Animal Health Research Reviews 1, 127-136.

- Sabban, M. S. (1957): The cultivation of sheep pox virus on chorioallantoic membrane of the developing chicken embryo. Am. J. Vet. Res., 18: 618- 624.

- Saber,M.S.(1992): Studies on lumpy skin disease in Egypt. LSD final report on the Scientific Progress of PI 480 project.

- Sambrook, J.E.; Fritsch, E.F. and Maiates, T. (1989): Molecular coloning laboratory Manual. $2^{\text {nd }}$ edition.

- Shi M.M (2001): Enabling large-scale pharmacogenetic studies by high- throughput mutation and genotyping technologies. Clinical Chemistry, 47, 164-172.

- Soad,M.; Wafaa,A.;Z Michae,A.;Fayed,A.A.and Taha,M.M. (1996): Studies on sheep and goats pox viruses from naturally infected animals. Assiut Veterinary medical J., 35 (70): 29-38. 
- Starm, Y.; Kuznetzova, L.; Friedgut, O.; Gelman, B.; Yadin, H. and Rubinstein-Guini, M. (2008): The use of lumpy skin disease virus genome termini for detection and phylogenic analysis. J. Virol. Methods, 151 (2): 225-229.

- Tawfik,A.;Ali,A.A.;Ibrahim,E.M.;mervat,M. Mahmoud and Shahin, M.A. (2001): Studies on sheep pox in Kafr-El-Sheikh Governorate. J. Egypt.Vet. Med.Ass.,6 (A):195-6.

- Tulman,E.R.;Afonso, C.L.; Lu, Z.; Zsak, L.; Kutish, G.F. and Rock, D.L. (2001): Genome of lumpy skin disease virus.J Viol Aug. 75 (15): 7122-7130.

- Tulman, E.R.; Afonso, C. L.; Lu, Z.; et al. (2002): The genome of sheep pox and goat pox viruses. J. Virol. 76 (12): 6054-6061.

- Tuppurainen,E.S.M.; Venter,E.H. and Coetzer, J. A. W. (2005): The detection of lumpy skin disease virus in samples of experimentally infected cattle using different diagnostic techniques. Onderstepoort J.Vet. Res., 72, 153-164.

- Yazici,Z.;Oguzuoglu, T.C. and Gumusova, S.O. (2008): Detection of phylogenetic analysis of local capripox virus from necropsy specimens of sheep suspected of sheeppox infection. Vlaams Diergeneeskundig Tijdschrift 78: 97-100.

- Zheng, M.; Liu, Q.; Jin, N.; Guo, J.; Huang, X.; Li, H.; Zhu, W. and Xiong, Y. (2007): A duplex PCR assay for simultaneous detection and differentiation of Capripoxvirus and Orf virus. Molecular and cellular probes 21 (4): 276-281. 
تفاعل البلمرة المتسلسل للتفرقة بين بعض معزولات مجموعة فيروسات الكابرى

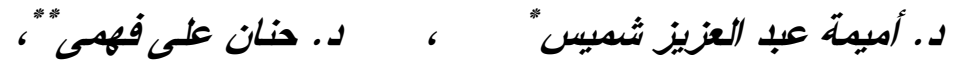

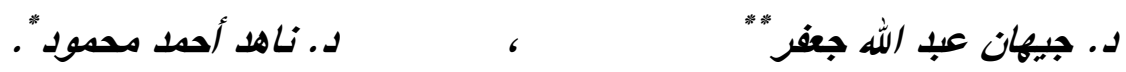

"قسم بحوث الفيرولوجى ، " قسم بحوث البيوتكنولوجى - معهد بحوث صحة الحيوان - الدقى - الجيزة.

في هذه الدر اسة نم فحص عدد 38 عينة جلدية من حيو انات مصابة إكلينيكياً (عدد 17 عينة

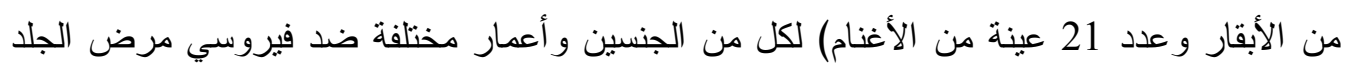
العقدي في الأبقار وجدري الأغنام.

نم أخذ عينات الأبقار من محطة شبرا شهاب بمحافظة القليوبية حيث كانت نسبة الإصابة 60\% ونسبة الوفيات 8\% وخصوصا فى الحيوانات الصغيرة, وقد أثبت الفحص الإكلينيكي وجود عقد جلدية وكانت عديدة فى الر أس و الرقبة للحيو ان وقد تغطى الجسم كله مع فقد الجزء المصاب من الجلد وفقدان في الثهية ونقص في الوزن مع قلة إدرار اللين.

كما نم أخذ عينات الأغنام من محطة سخا بمحافظة كفر الثيخ حيث كانت نسبة الإصابة 70\% ونسبة الوفيات 20\% وظهرت حويصلات على الأغنام المصابة مع تضخم في الغدد الليمفاوية. تم بنجاح عزل الفيروس على خلايا البيض المخصب وخلايا الزرع النسيجي ،كما تم التعرف على الفيروس باستخدام اختبار الأجار الترسيبي و الفلورسنت واختبار التعادل مع حساسية 42.2 \% ، \% \% 71.1 ، 65.8 \% على التو الي.

وكانت التقرقة بين فيروس الجلد العقدي وفيروس جدري الأغنام عن طريق تفاعل البلمرة المنسلسل المتعدد مع استخدام بادئ للتفاعل خاص بكل فيروس وكانت النتيجة 192 وحدة مزدوجة لمرض الجلد العقدي، 289 لفيروس جدري الأغنام.

وخلص البحث أن تفاعل البلمرة المتسلسل لايه الكفاءة و السرعة للتقرقة بين بعض فيروسات مجمو عة الكابرى و النتخيص مباثرة من الحالات الإكلينيكية. 